\title{
Higher Sensitivity in Induction of Apoptosis in Fibroblast Cell Lines Derived from LEC Strain Rats to Ultraviolet B Radiation
}

\author{
Masanobu HAYASHI ${ }^{1 *}$, Taku HAMASU1), Maiko TURUKAME1), Daiji ENDOH ${ }^{1)}$ and Toyo OKUI ${ }^{2)}$ \\ ${ }^{1)}$ Department of Veterinary Radiology, School of Veteriniary Medicine, Rakuno Gakuen University, Ebetsu 069-8501 and ${ }^{2)}$ Hokkaido \\ Institute of Public Health, Sapporo 060-0819, Japan
}

(Received 22 November 2000/Accepted 16 March 2001)

\begin{abstract}
When lung fibroblast cell lines from LEC and WKAH rats were irradiated with ultraviolet B (UVB) and assayed for colony formation, LEC rat cells showed a higher sensitivity than did WKAH rat cells. The LEC rat cells were approximately 1.5-fold more sensitive to UVB radiation than were the WKAH rat cells in terms of $\mathrm{D}_{37}$ values, which are the doses of UVB required to reduce cell survival to $37 \%$. When the rat cells were irradiated with UVB in the presence of $0.5 \mathrm{M}$ dimethyl sulfoxide (DMSO), which efficiently scavenges free radicals such as hydroxyl radicals, no significant difference was observed between the survival curves of either LEC or WKAH rat cells irradiated with UVB in the presence of 0.5 M DMSO and those irradiated with UVB in the absence of DMSO. Therefore, formation of free radicals may not be involved in cell death induced by UVB radiation. Flow cytometry showed that the percentage of apoptotic cells in the LEC rat cell population increased with post-incubation time after UVB radiation. The proportion of apoptotic cells in the UVB-irradiated LEC rat cell population increased as the dose of UVB was increased. In contrast, no significant proportion of apoptotic cells was observed in the UVB-irradiated WKAH rat cell population. These results showed a higher sensitivity in induction of apoptosis by UVB radiation in LEC rat cells than in WKAH rat cells.
\end{abstract}

KEY WORDS: apoptosis, colony assay, fibroblast, LEC strain rat, UVB radiation.

J. Vet. Med. Sci. 63(7): 709-713, 2001

Ultraviolet (UV) radiation in the middle wavelength between 290 and $320 \mathrm{~nm}$ (ultraviolet B, UVB) represents one of the most relevant environmental dangers because of its hazardous effects, such as induction of erythemia, skin aging, skin cancer, cataract and immunosuppression. UVB radiation causes cell death and DNA damage, although the dose of UVB necessary to induce these biological responses is much higher than that of ultraviolet C (UVC) from 200 to $290 \mathrm{~nm}$, which is not included in terrestrial UV on the earth's surface. UVC is directly absorbed by DNA, resulting in the formation of cyclobutane pyrimidine dimers and pyrimidine-pyrolidone (6-4) photoproducts (subsequently referred to as dimers and 6-4 photoproducts, respectively) in DNA [2]. It is well known that the dimers and 6-4 photoproducts produced by UVC radiation cause lethal damage to cells unless repaired [16]. Most of the dimers and 6-4 photoproducts of DNA are repaired, mainly by a nucleotide excision repair (NER) system, in normal cells [24, 25]. Since the dimers and 6-4 photoproducts are also produced by UVB radiation [2] and since NER-deficient human cells are sensitive to UVB radiation [15], it is thought that the induction of dimers and 6-4 photoproducts by UVB radiation represents a key step in the initiation of biological responses. However, there is accumulating evidence that other mechanisms such as a free radical formation and signal transduction activation of transcription factors may play important roles in the cellular responses caused by UVB radiation $[4,5,12,19,28,32]$. Thus, the mechanisms by which UVB radiation induces cellular responses are still controversial.

The LEC rat strain was established at the Center for Experimental Plants and Animals, Hokkaido University [26,
31]. Rats of this strain suffered from spontaneous fulminant hepatitis associated with severe jaundice at about 4 months of age. We previously reported that when cell survival was determined using colony-forming assay, the cells from LEC rats were more sensitive to $\mathrm{X}$-irradiation, but not UVC radiation, than were the cells from a control strain of WKAH rats $[6,20]$. On the contrary, LEC rat cells showed a higher sensitivity to induction of apoptosis by UVC radiation, but not $\mathrm{X}$-irradiation $[8,9]$. It is well known that $\mathrm{X}$-irradiation causes cellular damage by a formation of free radicals. Therefore, LEC rat cells provide a useful model for understanding the mechanisms of UVB-induced biological responses. In the present study, we found a higher sensitivity of cell lines derived from lung fibroblasts of LEC rats in reproductive cell death and in induction of apoptosis to UVB radiation.

\section{MATERIALS AND METHODS}

Culture of cells and UVB radiation: Rat fibroblast cell lines were established from lungs of LEC and WKAH rats by SV 40 immortalization as described previously [7]. The cells were grown in a monolayer culture in Eagle's minimum essential medium (MEM) containing 10\% fetal calf serum. The cell cultures were kept at ambient humidity and $37^{\circ} \mathrm{C}$ in an atmosphere containing $5 \% \mathrm{CO}_{2}$.

After the medium had been removed from the plates, the cells were washed with phosphate-buffered saline (PBS), $\mathrm{pH} 7.2$, and irradiated with UVB at a dose rate of $2.6 \mathrm{~J} / \mathrm{m}^{2} /$ sec using a Chromato-UVE lamp (Ultraviolet Products, Inc., CA, U.S.A.). The dose rate was measured with a UVX radiometer equipped with a UVX-32 sensor (Ultraviolet Prod- 
ucts, Inc., CA, U.S.A.). More than $95 \%$ of the ultraviolet emission from this lamp was at a wavelength of $320 \mathrm{~nm}$.

Colony-forming assay: Cell survival was determined using the conventional colony-forming assay. Propagated cells were collected by trypsinization, and $2-50 \times 10^{2}$ viable cells were plated into $6-\mathrm{cm}$ dishes. Immediately after UVB radiation, a fresh medium was added and the plates were returned to the incubator. The cells were incubated for 2 weeks. The dishes were methanol-fixed, stained with MayGrunwald and Giemsa, and then colonies containing more than 50 cells were counted as survivors under a dissecting microscope.

Flow cytometry: The apoptotic cells were labeled with fluorescein-dUTP by using a Mebstain apoptosis kit direct (Medical \& Biological Laboratories Co.) according to the manufacturer's instructions. Briefly, after UVB radiation, logarithmically growing cells $\left(1 \times 10^{6}\right)$ were incubated in growth medium at $37^{\circ} \mathrm{C}$ for $0-72 \mathrm{hr}$ and collected. The cells were washed several times with PBS containing $0.2 \%$ BSA. The cells were fixed with $0.1 \mathrm{M} \mathrm{NaH}_{2} \mathrm{PO}_{4}$ containing $4 \%$ paraformaldehyde at $4^{\circ} \mathrm{C}$ for $30 \mathrm{~min}$, washed 2 times with PBS containing $0.2 \% \mathrm{BSA}$, and then pelleted by centrifugation at $500 \times \mathrm{g}$. The cells were fixed in $5 \mathrm{ml}$ of cold $70 \%$ ethanol for $30 \mathrm{~min}$ at room temperature and stored at $-20^{\circ} \mathrm{C}$. Just prior to flow cytometric analysis, individual samples were labeled with fluorescein-dUTP. Fluorescence was measured with a Coulter EPICS EL flow cytometer using a 530-nm filter. The percentage of apoptotic cells was determined using multicycle software.

Analysis of DNA fragmentation by agarose gel electrophoresis: After UVB radiation, logarithmically growing cells $\left(1 \times 10^{8}\right)$ were incubated in growth medium at $37^{\circ} \mathrm{C}$ for 0-72 hr and low-molecular-weight DNA was extracted from the cells in essentially the same way as described by Herrmann et al. [10], except that Triton X-100 was used instead of Nonidet P-40. The extracted DNA was separated by electrophoresis through $1.5 \%$ agarose gel, stained with ethidium bromide, and then photographed under UV-transillumination.

\section{RESULTS}

When the lung fibroblast cell lines from LEC and WKAH rats were UVB-irradiated and assayed for colony formation, LEC rat cells showed a higher sensitivity than did WKAH rat cells (Fig. 1). The dose of UVB required to reduce cell survival to $37 \%\left(\mathrm{D}_{37}\right)$, which is an index used to compare cellular sensitivity, was $37 \mathrm{~J} / \mathrm{m}^{2}$ for LEC rat cells and $56 \mathrm{~J} /$ $\mathrm{m}^{2}$ for WKAH rat cells. The LEC rat cells were approximately 1.5 -fold more sensitive to UVB radiation than were WKAH rat cells in terms of $D_{37}$ values. Dimethyl sulfoxide (DMSO) efficiently scavenges free radicals such as hydroxyl radicals. To determine whether the formation of free radicals was involved in the cell death induced by UVB radiation, the rat cells were irradiated with UVB in the presence of 0.5 M DMSO. No significant difference was observed between the survival curves of either LEC or

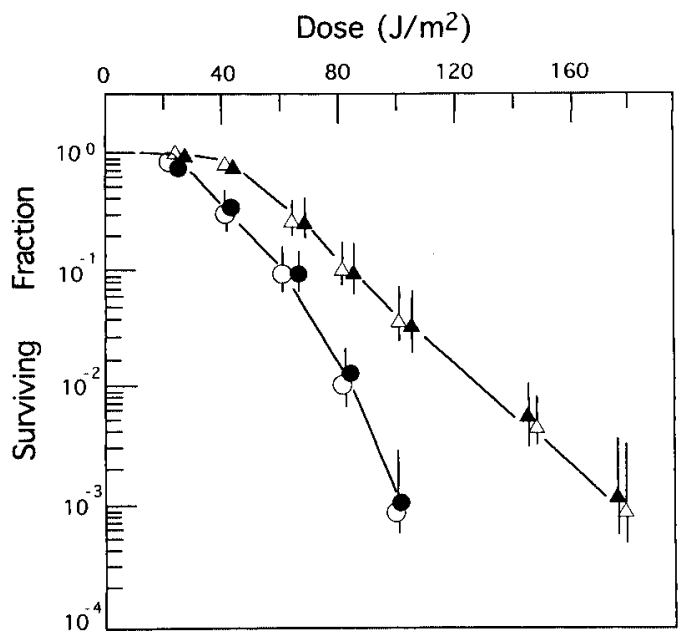

Fig. 1. Survival curves of cell lines from LEC and WKAH rats after UVB radiation. LEC $(\bigcirc, \bigcirc)$ and WKAH $(\triangle$, $\Delta)$ rat cells were irradiated with UVB in the absence $(O$, $\triangle$ ) and presence $(\boldsymbol{\Delta}, \mathbf{\Delta})$ of $0.5 \mathrm{M} \mathrm{DMSO}$, and they were assayed for colony formation. Points represent the average from four separate experiments. Error bars represent the standard deviations of mean values.

WKAH rat cells irradiated with UVB in the presence of 0.5 M DMSO and those irradiated with UVB in the absence of DMSO (Fig. 1).

To determine the sensitivity of LEC rat cells in UVBinduced apoptosis, fibroblast cell lines from LEC and WKAH rats were UVB-irradiated and incubated at $37^{\circ} \mathrm{C}$ for $0-72 \mathrm{hr}$, and then the proportion of apoptotic cells was determined using a flow cytometer. Typical results of flow cytometric analysis of the cells irradiated with UVB at 300 $\mathrm{J} / \mathrm{m}^{2}$ were shown in Fig. 2. In the case of LEC rat cells, the proportion of apoptotic cells increased with post-incubation time after UVB radiation. In contrast, apoptotic cells were not observed in the UVB-irradiated WKAH rat cells until 72 hr incubation. The percentage of apoptotic cells in the UVB-irradiated LEC rat cell population increased as the dose of UVB was increased (Fig. 3). In the case of WKAH rat cells, the proportion of apoptotic cells in the total cell population was lower than $3 \%$ until $72 \mathrm{hr}$ incubation after UVB radiation at $500 \mathrm{~J} / \mathrm{m}^{2}$ (Fig. 3). The proportions of apoptotic cells in the unirradiated and UVB-irradiated (at doses of 100 to $400 \mathrm{~J} / \mathrm{m}^{2}$ ) WKAH rat cell populations were lower than $3 \%$ until $72 \mathrm{hr}$ incubation (data not shown). These results showed a higher sensitivity in induction of apoptosis by UVB radiation in LEC rat cells than in WKAH rat cells.

When low-molecular-weight DNAs were extracted from LEC and WKAH rat cells that had been UVB-irradiated at $500 \mathrm{~J} / \mathrm{m}^{2}$ and analyzed using agarose gel electrophoresis, DNA extracted from UVB-irradiated LEC rat cells, but not that extracted from UVB-irradiated WKAH rat cells, exhibited an intense DNA ladder pattern corresponding to multiples of the nucleosomal sizes of 180-200 base pairs at 48 

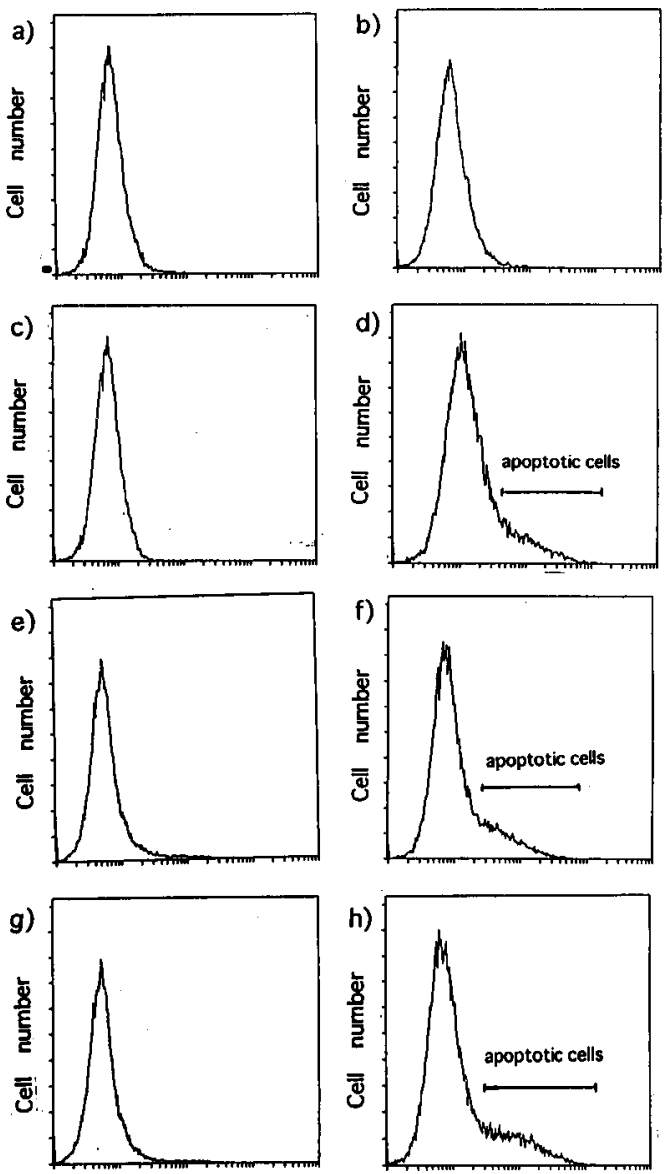

Fig. 2. Induction of apoptosis in WKAH and LEC rat cells after UVB radiation. After WKAH (a, c, e, g) and LEC (b, $\mathrm{d}, \mathrm{f}, \mathrm{h}$ ) rat cells were exposed to $300 \mathrm{~J} / \mathrm{m}^{2}$ of UVB, the cells were incubated at $37^{\circ} \mathrm{C}$ for $0(a, b), 24$ (c, d), 48 $(\mathrm{e}, \mathrm{f})$ and $72(\mathrm{~g}, \mathrm{~h}) \mathrm{hr}$, and apoptotic cells were analyzed by a flow cytometer at each incubation time.

and $72 \mathrm{hr}$ post-irradiation (Fig. 4). A DNA ladder appears as a result of internucleosomal enzymatic cleavages of DNA and is a biochemical hallmark of apoptosis.

\section{DISUCUSSION}

We previously reported that no differences were observed in the survival curves and the $\mathrm{D}_{37}$ values between LEC and WKAH rat cells after UVC radiation [20]. Those results suggested that the ability of LEC rat cells to repair of DNA damage such as dimers and 6-4 photoproducts is similar to that of WKAH rat cells. UVB radiation produces dimers and 6-4 photoproducts, although yields of dimers and 6-4 photoproducts produced by UVB radiation are much less than those by UVC radiation [2]. The present results showed that LEC rat cells have a higher sensitivity to UVB radiation than do WKAH rat cells, suggesting that the higher sensitivity of LEC rat cells to UVB radiation is not related to

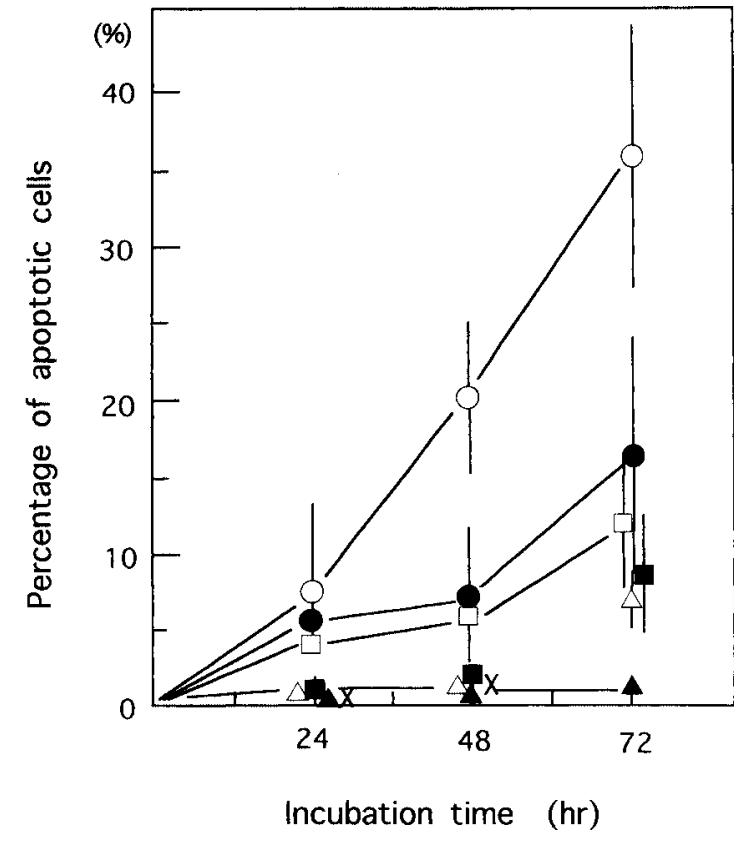

Fig. 3. Dose-dependent induction of apoptosis in UVB-irradiated LEC rat cells. After LEC rat cells were exposed to 0 $(\mathbf{\Delta}), 100(\triangle), 200(\square), 300(\square), 400(\bigcirc)$ and $500(\bigcirc) \mathrm{J} / \mathrm{m}^{2}$ of UVB and WKAH rat cells were exposed to $500 \mathrm{~J} / \mathrm{m}^{2}(\mathrm{x})$, the cells were incubated at $37^{\circ} \mathrm{C}$ for $0,24,48$ and $72 \mathrm{hr}$, and the proportion of apoptotic cells was detemined by a flow cytometer at each incubation time. Points represent the average from three separate experiments. Error bars represent the standard deviations of mean values. Standard deviations were within symbols at some points.

the repairability of dimers and 6-4 photoproducts and that dimers and 6-4 photoproducts may not be major lethal damage in the UVB-irradiated LEC rat cells. DMSO effectively scavenges free radicals such as hydroxyl radicals. No significant difference was observed between the survival curves of either LEC or WKAH rat cells irradiated with UVB in the presence of $0.5 \mathrm{M} \mathrm{DMSO}$ and those irradiated with UVB in the absence of DMSO (Fig. 1). Thus, free radical formation can not account for the higher sensitivity of LEC rat cells to UVB radiation, although some studies have shown that free radical formation may play an important role in the cellular responses by UVB radiation [4, 12, 32]. The presence of DMSO also did not affect the proportion of apoptotic LEC rat cells after UVB radiation (data not shown). It has been shown that there are some minor types of DNA damage produced by UVB and UVC radiation that differ qualitatively and quantitatively [2]. However, the lethal effect of such minor types of DNA damage on cells remains unknown.

The results of the present study showed that LEC rat fibroblasts were more sensitive to induction of apoptosis by UVB radiation than were WKAH rat cells. Therefore, the higher sensitivity of LEC rat cells in cell death to UVB radi- 


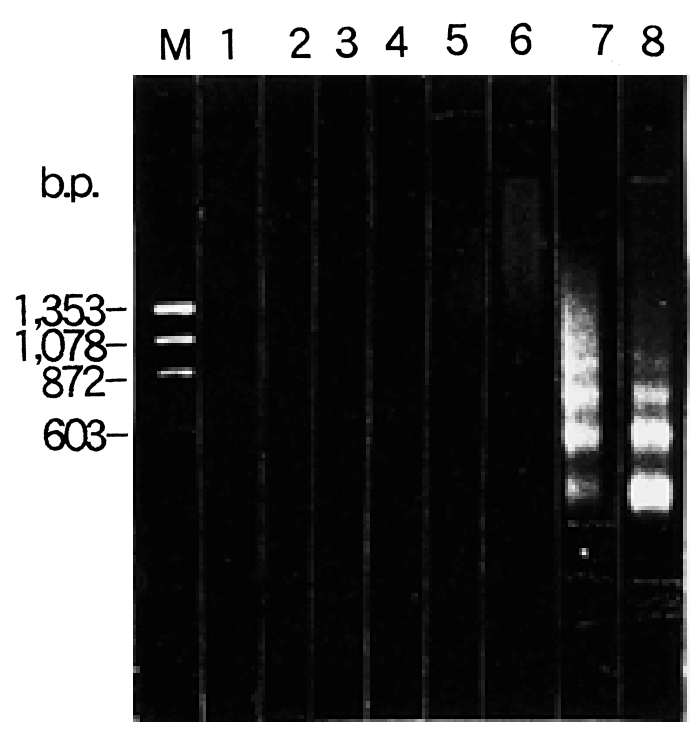

Fig. 4. Agarose gel electrophoresis of low-molecularweight DNAs extracted from UVB-irradiated WKAH and LEC rat cells. After UVB radiation at $500 \mathrm{~J} / \mathrm{m}^{2}$, low-molecular-weight DNAs were extracted from WKAH rat cells (lanes 2 and 3 ) and LEC rat cells (lanes 5-8) incubated at $37^{\circ} \mathrm{C}$ for 0 (lanes 2 and 5), 24 (lanes 6), 48 (lane 7) and 72 (lanes 3 and 8 ) hr, and analyzed by agarose gel electrophoresis at each incubation time. Lanes 1 and 4 represent DNA extracted from unirradiated WKAH and LEC cells, respectively. HaeIII-digested phiX-174 DNA was used as a molecular weight marker (lane M).

ation may be at least partly responsible for the high sensitivity in induction of apoptosis. It has been reported that UVB radiation induces cellular apoptosis both in vitro and in vivo $[1,13,14]$. UVB-induced DNA damage appears to be an important molecular trigger for the induction of apoptosis $[12,18,22]$. It has been shown that UVB radiation stabilized the p53 protein [13], which plays a critical role in mediating apoptosis in response to DNA damage [3, 30]. P53 protein is essential for transcriptional up-regulation of CD95 after DNA damage, resulting in induction of apoptosis [11]. Furthermore, it has been reported that the stabilization of p53 induces enhancement of galectin-7 mRNA and that galectin-7 participates in the process of UVB-induced apoptosis in the epidermis [1]. Our preliminary results showed that UVB radiation did not affect the $\mathrm{p} 53$ protein level in LEC rat cells (data not shown). Therefore, the expression of p53 protein might not be associated with the high sensitivity in induction of apoptosis in LEC rat cells after UVB radiation.

There is an accumulation of evidence that UVB radiation can induce apoptosis without a nuclear signal induced by DNA damage. It has been shown that UVB radiation directly activates death receptors on the cell surface, includ- ing CD95, implying that UVB-induced apoptosis can be initiated at the cell membrane through death receptor clustering [14]. Devary et al. [5] and Simon et al. [28] demonstrated that activation of the transcription factor $\mathrm{NF} k \mathrm{~B}$ following UVB radiation does not require a nuclear signal. It is well known that NFkB activates the expression of a variety of cytokines. UVB radiation has been shown to damage human keratinocytes in part by inducing production of cytokines, such as tumor necrosis factor (TNF)-alpha [21, 29]. Even more importantly, Rosette and Karin reported that UVB radiation can activate the Jun N-terminal kinase (JNK) cascade that induces apoptosis [23]. Furthermore, Shimizu et al. [27] reported that activation of p38 mitogenactivated protein kinase may play an important part in the apoptotic process of keratinocytes exposed to UVB radiation. Our preliminary results showed that there were no significant differences in sensitivities of cell death and induction of apoptosis in response to treatment with ceramide, which activates a stress-activated protein kinase/JNK cascade [17], between LEC and WKAH rat cells (data not shown). Furthermore, production of TNF-alpha might not be associated with a higher sensitivity of induction of apoptosis in LEC rat cells (data not shown). A study is now in progress to determine whether the induction of apoptosis in LEC rat cells by UVB radiation is dependent on DNA damage or not.

The results of previous studies $[6,8,9,20]$ and the present study have shown that LEC rat cells are more sensitive in cell death to $\mathrm{X}$-irradiation and UVB radiation, but not UVC radiation, than are WKAH rat cells. On the contrary, LEC rat cells show a higher sensitivity in induction of apoptosis to UVB and UVC radiation, but not $\mathrm{X}$-irradiation. Thus, LEC rat cells provide a useful model for understanding the mechanisms of UVB-induced biological responses, such as the repair process of UVB-induced DNA damage and induction of apoptosis.

ACKNOWLEDGEMENT. This work was supported in part by a grant-in-aid from the Ministry of Education, Science, Sports and Culture of Japan, and by the Science Research Promotion Fund by the Promotion and Mutual Aid Corporation for Private Schools of Japan.

\section{REFERENCES}

1. Bernerd, F., Sarasin, A. and Magnald, T. 1999. Galectin-7 overexpression is associated with the apoptotic process in UVB-induced sunburn keratinocytes. Proc. Natl. Acad. Sci. U.S.A. 96: 11329-11334.

2. Cadet, J., Anselmino, C., Douki, T. and Voituriez, L. 1992. Photochemistry of nucleic acids in cells. J. Photochem. Photobiol. B15: 277-298.

3. Calles, C., Jang, A., Peacock, P., Chung, S., Benchimol, S. and Hill, R.P. 1994. p53-dependent apoptosis in the absence of transcriptional activation of p53-target genes. Nature (Lond.) 370: 220-223.

4. Caceres-Dittmar, G., Ariisumia, K., Xu, S., Tapia, F. J., Bergstresser, P. R. and Takashima, A. 1995. Hydrogen peroxide 
mediates UV-induced impairment of antigen presentation in murine epidermal-derived dendric cell lines. Photochem. Photobiol. 62: 176-183.

5. Devary, Y., Rosette, C., DiDonnata, J. A. and Karin, M. 1993. NF-kappa B activation by ultraviolet light not dependent on a nuclear signal. Science 261: 1442-1445.

6. Hayashi, M., Okui, T., Endoh, D., Sato, F., Kasai, N. and Namioka, S. 1994. Radiation-hypersensitivity of LEC strain rats controlled by a single autosomal recessive gene. Mutat. Res. 314: 135-142.

7. Hayashi, M., Ishimori, K., Maeda, A., Watanabe, T., Arai, S. and Okui, T. 1996. Radioresistant DNA synthesis in fibroblast cell lines derived from LEC strain rats. Mutat. Res. 352: 117121.

8. Hayashi, M., Uehara, K., Kirisawa, R., Endoh, D., Arai, S. and Okui, T. 1997. Abnormal G1 arrest in the cell lines from LEC strain rats after X-irradiation. J. Vet. Med. Sci. 59: 769-773.

9. Hayashi, M., Uehara, K., Ichikawa, Y., Arai, S., Isogai, E. and Okui, T. 1998. Higher sensitivity in induction of apoptosis in fibroblast cell lines derived from LEC strain rats to UV-irradiation. J. Vet. Med. Sci. 60: 207-212.

10. Herrmann, M., Lorenz, H.-M., Voll, R., Woith, W. and Kalden, J. R. 1994. A rapid and simple method for the isolation of apoptotic DNA fragments. Nucleic Acids Res. 22: 5506-5507.

11. Hill, L. L., Ouhtit, A., Loughli, S. M., Kripke, M. L., Ananthaswamy, H. N. and Owen-Schaub, L. B. 1999. Fas ligand: a sensor for DNA damage critical in skin cancer etiology. Science 285: 898-900.

12. Ibbotson, S. H., Moran, M. N., Nash, J. F. and Kochevar, I. E. 1999. The effects of radicals compared with UVB as initiating species for the induction of chronic cutaneous photodamage. $J$. Invest. Dermatol. 112: 933-938.

13. Kane, K. S. and Maytin, E. V. 1995. Ultraviolet B-induced apoptosis of keratinocytes in murine skin is reduced by mild local hyperthermia. J. Invest. Dermatol. 104: 62-67.

14. Klums, D., Poppelmann, B., Yarosh, D., Luger, A. T., Krutmann, J. and Schwarz, T. 1999. Nuclear and cell membrane effects contribute independently to the induction of apoptosis in human cells exposed to UVB radiation. Proc. Natl. Acad. Sci. U.S.A. 96: 7974-7979.

15. Kondo, S., Fukuro, S. and Nishioka, K. 1991. Age-related changes in photosensitivity and cellular sensitivity to ultraviolet B in a xeroderma pigmentosum group E patient. Photodermatol. Photoimmunol. Photomed. 8: 79-83.

16. Lehman, A. R., Kirk-Bell, S., Arlett, C. F., Harcourt, S. A., de Weerd-Kastelein, E. A., Keijzer, W. and Hall-Smith, P. 1977. Repair of ultraviolet light damage in a variety of human fibroblast cell strains. Cancer Res. 37: 904-910.

17. Mosser, D. D., Caron, A. W., Bourget, L., Denis-Larose, C. and Massie, B. 1997. Role of the human heat shock protein hsp 70 in protection against stress-induced apoptosis. Mol. Cell. Biol. 17: 5317-5327.

18. Nishigori, C., Yarosh, D. B., Ullrich, W. E., Vink, A. A., Bucana, C. D., Roza, L. and Kripke, A. L. 1996. Evidence that DNA damage triggers interleukin 10 cytokine production in UV-irradiated murine keratinocyte. Proc. Natl. Acad. Sci.
U.S.A. 93: 10354-10359.

19. Noonan, F. P. and DeFabo, E. C. 1992. Immunosupression by ultraviolet B radiation: initiation by uronic acid. Immunol. Today 13: 250-254.

20. Okui, T., Endoh, D., Arai, S., Isogai, E. and Hayashi, M. 1996. Cross-sensitivity of X-ray-hypersensitive cells derived from LEC strain rats to DNA-damaging agents. J. Vet. Med. Sci. 58: 1067-1071.

21. Pei, L. C. and Travers, J. B. 1999. Augmentation of ultraviolet $\mathrm{B}$ radiation-induced tumor necrosis factor production by the epidermal platelet-activating factor receptor. J. Biol. Chem. 274: 26917-26921.

22. Petit-Fere, C., Clingen, P. H., Grewe, M., Krutmann, J., Rosa, L., Arlett, C. F. and Green, M. H. Induction of interleukin-6 production by ultraviolet radiation in normal human epidermal keratinocytes and in a human ketatinocyte cell line is mediated by DNA damage. J. Invest. Dermatol. 111: 354-359.

23. Rosette, C. and Karin, M. 1996. Ultraviolet light and osmotic stress: activation of the JNK cascade through multiple growth factor and cytokine receptors. Science 274: 1194-1197.

24. Sancar, A. 1994. Mechanisms of DNA excision repair. Science 266: $1954-1956$

25. Sancar, G. B., Siede, W. and van Zeeland, A. A. 1996. Repair and processing of DNA damage: a summary of recent progress. Mutat. Res. 362: 127-146.

26. Sasaki, M., Yoshida, M.C., Kagamori, K., Takeichi, N., Kobayashi, H., Dempo, K. and Mori, M. 1985. Spontaneous hepatitis in an inbred strain of Long-Evans rats. Rat News Lett. 14: 4 6.

27. Shimizu, H., Banno, Y., Sumi, N., Naganaka, T., Kitayama, Y. and Nozawa, Y. 1999. Activation of p38 mitogen-activated protein kinase and caspases in UVB-induced apoptosis of human keratinocyte HaCaT cells. J. Invest. Dermatol. 112: 769-774.

28. Simon, M. M., Aragane, Y., Schwartz, A., Luger, T. A. and Schwartz, T. 1994. UVB light induces nuclear factor kappa B (NF kappa B) activity independently from chromosomal damage in cell-free cytosolic extracts. J. Invest. Dermatol. 102: 422-427.

29. Skov, L., Hansen, H., Allen, M., Villadsen, L., Barker, J. N., Simon, J. and Baadsgaard, O. 1998. Contrasting effects of ultraviolet A1 and ultraviolet B exposure on the induction of tumor necrosis factor-alpha in human skin. Br. J. Dermatol. 138: $216-220$

30. Yonish-Rouach, E., Grunwald, D., Wilder, S., Kimchi, A., May, E., Lawrence, J.-J., May, P. and Oren, P. 1993. p53mediated cell death: relationship to cell cycle control. Mol. Cell. Biol. 13: 1415-1423.

31. Yoshida, M.C., Masuda, R., Sasaki, M., Takeichi, N., Kobayashi, H., Dempo, K. and Mori, M. 1987. New mutation causing hereditary hepatitis in the laboratory rat. J. Hered. 78: 361365 .

32. Zhang, X., Rosenstein, B. S., Wang, Y., Lebwohl, M. and Wei, H. 1997. Identification of possible reactive oxygen species involved in ultraviolet radiation-induced oxidative DNA damage. Free Radic. Biol. Med. 23: 980-985. 